\title{
LOC syndrome
}

INSERM

\section{Source}

INSERM. (1999). Orphanet: an online rare disease and orphan drug data base. LOC

syndrome. ORPHA:2407

LOC syndrome is a subtype of junctional epidermolysis bullosa (JEB, see this term) characterized by an altered cry in the neonatal period and by aberrant production of granulation tissue in particular affecting the upper airway tract, conjunctiva and periungual/subungual sites. 